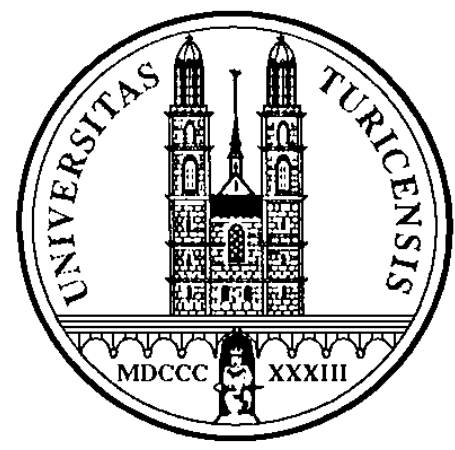

Institute for Empirical Research in Economics

University of Zurich

Working Paper Series

ISSN 1424-0459

published in:

Kyklos, Vol. 52, 1999, 555-572

Working Paper No. 8

\title{
Intra-firm Wage Dispersion and Firm Performance
}

Rudolf Winter-Ebmer and Josef Zweimüller

May 1999 


\title{
Intra-firm Wage Dispersion and Firm Performance
}

\author{
Rudolf Winter-Ebmer \\ University of Linz, WIFO Vienna and CEPR, London \\ Josef Zweimüller \\ University of Zurich and CEPR, London
}

forthcoming in:

Kyklos (1999)

This research has been supported by a grant from the Austrian Central Bank (Jubiläumsfonds \#4674 and \#6819/2) and from the Austrian Science Funds (J01082). Thanks for valuable comments by G. Akerlof, G. Baker, C. Brown, M. Brown, J. Brunner, J. Falkinger, S. Gächter, J. Leonard, D. Levine, S. Raphael, R. Schnabel, L. Ulman, and seminar participants at Berkeley, Linz and at the Society of Labor Economists, Chicago. Markus Gusenleitner provided excellent research assistance. 


\begin{abstract}
Personnel economics has put forward conflicting arguments concerning the impact of increased wage dispersion within a firm on the productivity of its workers. Besides giving more incentives, bigger wage differentials might also give rise to less co-operation and more politicking amongst workers resulting in worse outcomes. We try to shed light on these issues using panel data for Austrian firms. As indicators for firm performance we use standardised wages. For white-collar wages the following picture emerges: more dispersion leads to higher earnings up to some point where the relation changes its direction. For blue-collar wages we find a positive association between dispersion and standardised wages between firms, but no relation within firms over time.
\end{abstract}

\title{
Zusammenfassung
}

In der Arbeitsmarkttheorie werden gegensätzliche Ansätze über den Einfluß einer erhöhten Streuung der Löhne auf die Produktivität der Arbeiter eines Unternehmens diskutiert. Neben der Verstärkung von Karriere-Anreizen können größere Lohndifferentiale auch zu einer Verminderung der Kooperation sowie zu mehr „Politicking“ innerhalb der Arbeiter führen, was die Ergebnisse verschlechtern kann. Wir versuchen in diese Fragestellungen etwas Licht zu bringen, indem wir Paneldaten für österreichische Firmen verwenden. Wir verwenden standardisierte Löhne als Indikator für die Firmenleistung. Für die Gehälter von Angestellten entsteht das folgende Bild: eine höhere Streuung führt zu höheren Löhnen bis zu einem Punkt, wo sich diese Relation umdreht. Was die Löhne der Arbeiter betrifft, so finden wir eine positive Beziehung zwischen der Streuung und den standardisierten Löhnen zwischen den Firmen, nicht aber innerhalb der Firmen über die Zeit.

\section{Résumé}

La théorie économique du personnel propose des approches conflictuelles quant à l'impact, au sein d'une entreprise, d'un accroissement de la dispersion des salaires sur la productivité de ses employés. Outre le fait d'inciter à l'avancement, de plus grandes différences de salaires pourraient aussi mener à une moindre coopération et à plus de "politicking" entre les employés, provoquant ainsi des résultats plus mauvais. Nous essayons d'illustrer ces positions en utilisant un panel d'entreprises autrichiennes, les salaires standardisés servant d'indicateur de performance pour chaque firme. Concernant les salaires des cols blancs, on remarque qu'une plus grande dispersion conduit à des revenus plus élevés jusqu'à un point où cette relation s'inverse. Quant aux salaires des cols bleus, on note une association positive entre dispersion et salaires standardisés entre les firmes mais aucune relation au sein des firmes dans le temps.

JEL: D 31, J 33, J 53

Keywords: wage dispersion, incentives, firm productivity 


\section{Introduction}

The last years have witnessed a general rise in interest concerning income distribution and its economic consequences. This is mainly the result of rising income disparities in many countries, first of all in the U.S. Inequality has increased for the population as a whole but also within specific industries, between groups of workers defined by educational attainment as well as within firms. The latter received much media attention as CEO's compensation grew rapidly relative to the salaries of the general work-force.

The appropriateness of high executive compensation schemes or a very steep earnings profile within the firm, can be questioned on grounds of morality or fairness. There is not much an economist can contribute to this discussion. On the other hand, economic theories do relate productivity in the firm to firm organisation, especially the compensation structure. Incentive arguments - most evident in the form of tournament models - argue for a higher wage spread in order to motivate workers to aspire to superior positions. Other theories stress that co-operation between workers and general fairness considerations act as a constraint on overly dispersed pay schedules: Cooperation between workers might suffer, politicking activities to influence the distributional process in the firm might increase and, thus, ultimately destroy the positive incentive effect of higher wage dispersion.

To test these theories we use a data set for Austrian firms, in which we observe wages for the whole work-force over several years. As we cannot observe the financial performance of the firms, we construct a different performance measure: standardised wages for different workers. We find that the earnings of white-collar workers react in a hump-shaped way to wage inequality in the firm: at first, more inequality increases earnings, but at some point the relation reverses. More inequality above the mean of our empirical observations is detrimental to the productivity of white-collar workers, as far as their productivity can be inferred from their wages. In the case of blue-collars, the standardised wage increases with wage dispersion. Only at very high inequality measures do standardised blue collar wages start to decline with increased dispersion.

The plan of the paper is as follows. The next section discusses theories of inequality and firm performance and reviews the relevant empirical literature. Section 3 presents our data and derives our performance indicator as well as the firm wage inequality measure. In section 4 we present our results based on the pooled sample. These results are a mixture of the within- and between-firm effect of wage dispersion on worker productivity. In section 5 we apply panel- 
data methods to see to which extent the observed relationship results from variation within or between firms. The former can be interpreted as a short-term, the latter as a long-term phenomenon. It turns out that both for blue- and for white-collar workers, the (long-term) between-firm inequality-productivity relationship is of quantitative significance. Short-term changes in firm wage inequality have a statistically significant but quantitatively minor impact on standardised white-collar wages. No such short-term relationship can be detected for bluecollar workers. Section 6 concludes.

\section{Wage dispersion and firm performance}

Employers can decide between absolute and relative compensation schemes. One example of the latter is the theory of rank-order tournaments (Lazear and Rosen, 1981). Workers are not rewarded according to their absolute performance, but according to whether they are better or worse than their fellow workers. The better player receives the premium which may be thought as a promotion. This compensation scheme leads to higher equilibrium effort by both workers the higher the wage spread between the good and bad jobs. High wage dispersion enhances productivity.

On the other hand, fierce competition between workers may be detrimental to the firm. A worker can increase his chances of winning a contest by increasing his effort, but also by trying to reduce the output of his contestant through means of sabotage or non-cooperation. Lazear (1989) shows that some wage compression is optimal in this situation. He distinguishes more aggressive, and thus sabotage-prone, workers ("hawks") from less aggressive ones ("doves"). The firm would like to employ only doves if the different types could be identified. The optimal reaction is to introduce a more equitable wage structure, if one is found with many hawks in the firm. One implication of such an environment is a positive correlation between wage inequality and mean productivity in a cross-section of firms: Firms with only doves are able to introduce steeper incentive schedules leading to both more inequality and higher mean productivity, whereas "hawkish" firms must refrain from such schemes. The empirical relation between inequality and productivity is thus caused by a different workforce composition within firms.

Similar arguments relate to influence and rent-seeking activities in firms (Milgrom, 1988; Milgrom and Roberts, 1990). Workers can engage in costly rent-seeking instead of productive 
work, if there is much potential for redistribution at the discretion of a supervisor. Remedies to limit these costs are to compress the firm's overall wage structure, thus limiting access of employees to the decision making process or reducing management discretion over decisions that are of little importance to the organisation, but have potentially large redistributive consequences. Although some pay compression emerges as an efficient outcome, there are no clear testable relations between compression and firm outcome.

A further strand of the literature relies on efficiency wages and fairness. Wage dispersion or compression may become an important decision variable for the firm once employees engage in social comparison. Workers might assess the appropriateness of their pay relative to the compensation of a reference group and act correspondingly in providing effort. Based on equity theory (Adams, 1963), Akerlof and Yellen (1990) postulate that workers withdraw effort if their actual wage falls short of the wage the workers themselves consider as fair. This fair wage, in turn, can be determined as a weighted average of wages of a reference group and the respective market-clearing wage. Fehr, Gächter and Kirchsteiger (1996) provide experimental evidence for this argument. The distribution of rents is compressed due to considerations of fairness. A related argument is also put forward by Levine (1991). In participatory firms where work groups are important, cohesiveness will further productivity. As pay compression increases group cohesiveness, wage compression augments overall productivity. Although egalitarian policies might be advisable in the light of social comparison, firms may face difficulties, because top performers tend to leave the firm.

Explicit incentive contracts can also have detrimental motivational side-effects. Especially in the psychological literature intrinsic motivation is seen as the main driving force for work effort and the mastering of tasks. Frey (1997) as well as Frey and Osterloh (1997) discuss the possible crowding out of intrinsic motivation by the use of explicit incentive contracts. If external intervention supports the individual's own motivation, self-esteem and the feeling of competence on the job, it can enhance intrinsic motivation. On the other hand, crowding out can occur if the loss of self-determination caused by monitoring is decisive.

Early empirical evidence on the equity-productivity nexus stems mainly from social psychologists. Akerlof and Yellen (1990) as well as Levine (1991) review experiments along these lines, which generally stress relative remuneration and fair wages. Additional evidence comes from surveys conducted with personnel managers concerning their daily practices. Blinder and Choi (1990) and Agell and Lundborg (1995) use similar questionnaires in New

${ }^{1}$ Gächter and Falk (1998) review some experimental results on this issue. 
Jersey and in Sweden, respectively. They find that employers are particularly afraid of implementing an "unfair wage policy": they fear that turnover will rise, effort will fall and the quality of future applicants will suffer. Likewise, most employers dismiss wage cuts because of relative wage considerations. 3 Similarly, Levine (1993) finds that compensation executives are very reluctant to change the internal pay structure in response to different market wage developments for different groups of their work-force. This was especially so, if these groups worked closely together in the firm.

Not only incentive considerations or co-operation issues link earnings inequality to firm performance. In particular, there might be an underlying factor affecting both. One such factor is unionisation or worker organisation. On the one hand, unionised firms seem to have lower wage dispersion among observationally equal workers (Freeman, 1982). This may be due to the fact that pay compression enhances organisational strength and solidarity. Alternatively, union members may prefer more equality. On the other hand, unionised firms pay better. Other things being equal we would therefore expect to see less dispersion in firms with higher wages.

Another factor that may determine both firm performance and within firm wage dispersion is plant size. It is a well established fact that larger firms pay higher wages. may also exist a systematic relationship between inequality and employer size. For instance, due to the use of more standardised technologies larger employers might offer more homogenous jobs leading to less variation in pay. Similarly, larger firms are more likely to be unionised so that the above reasoning applies.

Non-experimental tests of theories relying on co-operation and incentive arguments are rare. This is mainly due to a lack of firm level inequality data. Macroeconomic papers

\footnotetext{
2

Unfortunately no clear definition of such an unfair wage policy is given in the questionnaire.

3 Bewley (1998) conducted in-depth interviews with managers. They regard a fair internal pay structure as vital, and any violations thereof as potentially disruptive. Moreover, equity may also restrain management from paying the best performers the full value of their contribution, thus leading to pay compression.

This seems to be less a problem in the case of Austria where union contracts are generally extended to all workers, regardless whether they are union members or not. 5 6

See Brown and Medoff (1989) for the U.S. and Winter-Ebmer and Zweimüller (1999) for Switzerland.

See Davis and Haltiwanger (1996) for evidence on decreasing wage dispersion across size classes inthe U.S. They conclude that the largest contribution to this narrowing wage dispersion in larger firms comes from the contribution of unmeasured worker characteristics.

${ }^{7}$ The papers by Baker at al (1994a,b) use data with detailed information on the compensation of workers at various positions within one firm. However, their objective is not primarily in studying the impact of wage compression.
} 
looking at inequality and growth or productivity generally use only economy-wide inequality indicators. One exception is Hibbs and Locking (1995) who study the Swedish experience from 1963 to 1993. In an aggregate production framework, they look at the relation of wage dispersion within and between firms on aggregate output. They find that higher wage dispersion between firms tends to reduce output, but output is furthered by higher dispersion within the firms. The overall effect of inequality on output is slightly negative. This result is in contrast to theories of within-firm worker cohesion and fairness considerations. However, the highly aggregated nature of this data set restricts its applicability. The results could be driven by the large wage compression in Sweden in the 1960s and 1970s, a development which was substantially reversed in recent years. The authors themselves entertain the possibility that "wage leveling in Sweden went far beyond the (unspecified) magnitudes that advocates of 'fairness, morale and cohesiveness' theories have in mind" (1995, p.22).

Cowherd and Levine's (1992) approach comes closest to ours. They look at a specific measure of firm performance: customer-assessed product quality. Using data for 102 business units in the US and UK they relate product quality to two measures of within-firm inequality: i) the pay relation of managers to hourly paid employees and ii) the pay differential between higher and lower management positions. For both inequality indicators they find a negative association with firm product quality. The authors attribute these findings to the impact of pay equity on employee commitment to managerial goals, effort and co-operation. The use of quality instead of quantity of production (productivity) may lead to another interpretation of the findings. If workers receive performance pay based on the quantities they produce, they might tend to neglect other - less observable - tasks like quality (Milgrom and Roberts, 1992).

Another interesting paper is Leonard (1990). His measure of firm performance is the return on investment, while his inequality measures are related only to managers. He is unable to find any effect of inequality on firm performance: Pay differentials and the number of hierarchies within management positions are not related to returns on investment or the change thereof over time.

\section{Data and indicators for performance and inequality}

\footnotetext{
8

Pfeffer and Alison-Blake (1992) look at the effect of wage dispersion on labor turnover, but they use only a very special data set for college administrators.
} 
To assess the impact of the wage structure on firm performance we use a panel of Austrian firms covering the period 1975-1991. The data originate from social security records. We sampled each 50th firm and collected all available information of the workers of these firms. This procedure has the advantage that the earnings structure of each firm in the sample is (almost) perfectly observable. We use firms with more than 20 employees and restrict the panel to those firms for which at least four data points are available. This results in a sample of 130 firms. Most of the variables used in typical wage regressions are available, except for education. The data report monthly earnings. Earnings are top-coded, affecting approximately $9 \%$ of the sample.

Concerning wage compression within firms, two basic concepts can be distinguished: (i) wage differentials between unequal workers and (ii) differentials between "observationally equal" workers. The first concept refers to the male/female or the blue/white collar pay gap, or to general measures of inequality, like Gini indices, Atkinson indices and the like. These indices do have appeal, when it comes to the influence of CEO's pay on work morale of the rest of the work-force, or the relations between different work-groups, as discussed by Akerlof and Yellen (1990). For our purpose these measures are less practical. Owing to our top-coding problem, no information on executives is available, so looking at the influence of managers' compensation is impossible. On the other hand, many theories like tournaments rely on the interaction of similar workers. A pay spread as an incentive for being promoted is only effective for those who compete for the same superior job, i.e. workers with a similar job situation. Likewise, industrial politics, non-cooperation, and sabotage is more easily established between workers at an equal job level. Following these lines, the pay structure should, therefore, account for different observable productivities, and only the residual inequality should matter. As suggested by Lazear (1989), we compute a conditional wage differential, conditional on observable characteristics of workers.

For each firm and each year a separate tobit earnings regression is run in the following way:

$$
\begin{array}{ll}
\quad \ln W_{i j t} *=a_{j t}+\sum_{k} b_{k, j t} Z_{k, i j t}+\varepsilon_{i j t} \\
\ln W_{i j t}=\ln W_{i j t} * & \text { if earnings are not top-coded } \\
\ln W_{i j t}=\ln T_{t} & \text { if earnings are top-coded at } T_{t} .
\end{array}
$$


$\mathrm{j}$ indexes firms and t time, $\mathrm{i}$ is the index for individuals. The explanatory variables include age, age squared as well as dummies for sex, blue-collar, foreigner status and two tenure dummies. The standard errors of these regressions are taken as the conditional wage differential sigma $\mathrm{jt}_{\mathrm{t}}$ for the firm $\mathrm{j}$ in time $\mathrm{t}$. This gives us a measure of wage compression for the firm controlling for observable differences of the work-force. Since regression (1) is run for each firm and for each year separately, sigma varies not only between firms but also over time within a given firm. Of all firm/year observations the mean of sigma is equal to 0.205 with a standard deviation of 0.074 . As we only observe monthly wages and no weekly hours, we might get biased inequality indicators if some workers are only employed part-time. A firm with more part-time workers - carrying lower monthly wages - would erroneously look like a firm with high wage dispersion. As only a negligible percentage of men work less than 40 hours, we calculate a second firm inequality measure based only on male workers in the firm.

Unfortunately no direct productivity or profitability measures are available in the data to measure firm performance. Instead we will focus on wage levels - a likely proxy for firm productivity. ${ }^{10}$ When firms pay their employees their marginal product, the firm wage level can be directly used as a measure of efficiency. Even when this is not the case, wage levels may still be a useful indicator for firm performance. Consider, for instance, a situation in which firms and workers split the firm's rents in a bargaining framework or according to a sharing rule. Whenever the pie becomes larger due to higher productivity, we would also expect workers to be paid better; even if they do not earn exactly the marginal product.

A natural choice for the earnings indicator would be the mean or median income. Unfortunately, these measures are heavily influenced by the composition of the work-force and intra-firm pay dispersion itself. Therefore, we calculate two standardised earnings indicators: expected earnings of a "typical" white-collar and a "typical" blue-collar worker. To construct these indicators we use the coefficients from the firm-specific wage equations and calculate for each firm expected earnings for a male white-collar (blue-collar) worker, 40

\footnotetext{
9 Of course, the relation would be vice versa, if the majority of workers in a firm were employed part-time: observing more part-time workers would tend to lower measured wage dispersion. 10

In a preliminary analysis we used also employment growth as another medium-term productivity indicator. No consistent results were found for this indicator. Detailed results can be received from the authors upon request.

See e. g. Blanchflower, Oswald and Garrett (1990) for the impact of internal profitability on pay in the U.K. Similar evidence for the U.S. is produced by Blanchflower, Oswald and Sanfey (1996).
} 
years old with Austrian nationality and 3 years of tenure in the firm. These firm-specific standardised wages were deflated using a consumer price index.

The data show a substantial pay difference between the "typical" blue collar and white collar worker. The average pay gap amounts to somewhat less than $40 \%$. Since the individual wage regressions (1) do lack information on schooling, the blue-collar/white-collar gap also reflects differences in formal education. For both, the "typical" white-collar and the "typical" blue-collar worker the standard deviation of log wages is somewhat larger than 0.40 , which seems to be relatively high. It should be noted, however, that this variation is not only due to between-firm wage differences, but also due to wage changes over time.

The remaining variables used in the subsequent analysis include plant size as well as variables describing the structure of the firm's workforce. We account for the age distribution of employees by using the share of younger and older workers in employment, the share of blue-collar and foreign workers, the percentage female as well as the share of workers with more than 3 years tenure.

\section{Wage Inequality and Firm Performance}

In this section we present our results using pooled firm-level data for standardised bluecollar and white-collar wages. The basic specifications for standardised wages are contained in Table 1. Within-firm inequality (sigma) is entered in a quadratic form to allow for a nonlinear relationship. The pattern for wages is, in general, hump-shaped. Blue-collar wages rise with inequality, but decline again after a peak at firm wage inequality of 0.29 , which is around three-half standard deviations above the mean of the firm inequality measure sigma (0.205). Thus, in general, the picture is positive.

The case is different for white-collar wages: Again, wages rise with inequality, but they already start to decline when the inequality indicator sigma takes on a value of 0.23 which is is close to its mean (0.205). Too much inequality is detrimental for productivity, as far as productivity is associated with wage levels. The quantitative effects of wage dispersion are as follows: Blue-collar workers' wages rise by $3.4 \%$ if the worker is employed at a firm with dispersion one standard deviation above the mean. In the case of white-collars, wages would

\footnotetext{
12 Wages could also be determined by an implicit life-cycle contract, above productivity at the beginning and below productivity at the end of the career. In this case, our standardised wage picks up a point in the middle of the career, where the deviations from productivity should be minor.
} 
fall by $2.1 \%$. These results suggest that white-collar workers exhibit a strong hump-shaped pattern, whereas blue-collar workers follow a rising inequality-wage profile over the main part of the earnings distribution.

Table 1

Control variables include firm size as well as several demographic characteristics of the work-force in the firm. Note that the dependent variables are firm-specific standardised wages, so the composition of the work-force should have no influence on the estimates. Interestingly however, most OLS-coefficients are highly significant.

The age structure in the firm serves as a proxy for the experience of the work-force. The percentage of prime-age workers in the firm fosters productivity; more youngsters as well as more elderly workers reduce standardised wages for white- and blue-collar workers alike. Interestingly, a high share of blue-collar workers is furthering wages for both groups. The same applies for a higher share of foreigners in the firm. The latter observation can be accounted for by a bargaining situation, where primary workers (natives) profit from the presence of secondary underpaid foreigners. A higher share of females reduces wages considerably. All these demographic variables in the OLS model can be seen as picking up structural components of firms, e.g. lower wages and productivity in women-dominated industries, such as textiles, etc. Contrary to prior reasoning of possible positive external effects of human capital, a more tenured work-force has a somewhat negative impact on standardised wages. Firm size is insignificant for blue-collar wages, but negative in the case of white-collar wages.

Table 2

Table 2 performs some robustness checks for the wage regressions. As the inequality indicator may be contaminated by different weekly working hours, we present here estimates where the inequality indicator sigma is calculated only for male employees in the firms. The results corroborate the previous findings. For blue-collar wages a positive pattern emerges: higher dispersion leads to higher wages for the most part of the empirical distribution of the

\footnotetext{
13 See Winter-Ebmer and Zweimüller (1996) for a model.

14 See Winter-Ebmer (1994) for an empirical examination of external effects of human capital accumulation.
} 
firm wage-inequality measure sigma. For white-collars, wages rise, but fall again after a value of sigma of 0.22 . This means that the results are quite robust with regard to the firm inequality measure.

Which of the aforementioned theories can explain these results, and in particular the difference between white- and blue-collar workers? Lazear's (1989) theory of hawks and doves would predict a rising dispersion-wage schedule, if firms have a different hawk/dove workforce composition. Empirically, we found such a positive dispersion-earnings relation only for blue-collars. The fact that no such relation was found for white-collars, would imply more potential for hawkish behaviour in the case of blue-collar workers. Therefore, it would pay more for firms to separate hawks and doves among the lower ranks of the firm. This is at odds with the casual observations, but also the general implications of the model: the prevalence of hawks and the potential of hawkish behaviour are more common in the higher ranks of the firm. The pattern for white-collar wages seems, thus, to be more in line with the cohesiveness and fairness arguments of Levine (1991) and Akerlof and Yellen (1990).

Furthermore, union behaviour cannot explain our results. If unions go for higher wages and less dispersion, we should find a more negative relation between standardised wages and wage dispersion in more unionised sectors. We observe the opposite: in the more unionised blue-collar sector we find a positive association between dispersion and wages throughout. Models of incentive pay (Milgrom and Roberts, 1992) with risk averse workers would imply a generally positive relation between dispersion and wages. If high wage dispersion is caused by a high incentive parameter in the wage schedule, risk averse workers have to be compensated for the higher incurred risk by higher average wages.

Why are the effects for blue- and white-collar workers different? A possible explanation for the positive influence of wage dispersion on average pay for blue-collar workers might be the existence of piece rates. The implementation of piece rates will increase wage dispersion, but will, on the other hand, also increase mean productivity, because, in general, workers will put in more effort, but also because top-performers will stay in the piece-rate firms. If some firms use piece rates whereas others don't, we might expect to find a positive dispersionearnings relation. As piece rates are only a relevant phenomenon for blue-collar workers, this might explain our positive inequality-wage schedule there.

On average, white-collar workers hold the better jobs, characterized by more responsibility and better advancement prospects. A possible consequence is more

15 See Lazear (1996) for a model and a very interesting case study. 
identification with the job and thus a higher importance of intrinsic motivation (Frey, 1997). A strong link of pay to performance for the better jobs may increase monitoring and crowd out intrinsic motivation. In that case, more wage inequality in the firm goes hand in hand with lower average performance. The downward sloping inequality wage schedule becomes more likely.

For blue-collar workers, the information problem concerning output is likely to be less severe than for white-collar workers. As a result, the scope for redistributive by supervisors and rent-seeking behaviour by workers actions - as considered by Milgrom and Roberts (1990) - may be bigger for white-collars than for blue-collars. This is another reason why the inequality-wage schedule could be of smaller importance for blue-collars than for whitecollars.

To sum up, our results are more in line with incentive considerations together with a fairness constraint. 16 They are not compatible with theories of hawks and doves, with simple models of risk aversion and with models of union influences. Our contrasting results for blueand white-collar workers are in line with theories of intrinsic motivation, within-firm rentseeking behaviour and also with the prevalence of piece rates in blue-collar jobs.

16

See Falkinger (1999 forthcoming) for a model from a public finance perspective, deriving a range of possible income distributions which are feasible in terms of incentives and social stability. 


\section{Standardised Wages and Firm Wage-Inequality Within and Between Firms}

The above results refer to the OLS regressions. The variation in these regression comes both from variation within a firm over time and from persistent differences between firms. It is interesting to know whether the relationship estimated by OLS is driven by short-term or long-term considerations. On the one hand, you might think that workers react immediately by reducing their effort to, say, perceived unfair treatment. On the other hand, wage inequality cannot be directly observed by the worker and is only gradually revealed within a firm. In particular, it may be difficult to differentiate between a random or a permanent change in the wage structure. The latter arguments would call for a stronger long-term relationship between firm wage inequality and pay.

In order to shed light on these issues we apply panel data methods. The first and third column of Table 3 introduce firm fixed effects. These estimates refer to the impact of changes in inequality over time within a firm on standardised wages and thus refer to shortterm effects. For both blue- and white-collar standardised wages, the U-shaped relationship between inequality and pay is much flatter compared to the OLS-estimates of Tables 1 and 2 . This can be seen from the (in absolute terms) smaller coefficients for the firm equality measure sigma (and sigma ${ }^{2}$ ). While for blue-collar workers the effect is insignificant, the results for white-collars are somewhat inconclusive. In Table 4 we check the robustness of our results. Here the turning point of the hump-shape is very similar to the one found in the OLSregression, whereas the coefficients in Table 3 indicate a positive inequality wage relation over the most part (up to two standard deviations above the mean) of the inequality scale.

Especially for blue-collar workers, the fixed effects estimates reveal a limited impact of temporary changes in within-firm wage dispersion on firm outcomes. As the compensation system of a firm cannot be expected to change very much over time, measurement errors might lead to downward-biased coefficients.

In order to see whether there is a long-term relationship between firm wage inequality and firm performance we focus the analysis on long-run firm-specific averages ("groupmeans") of the interesting variables. These group-means regressions of the performance indicators use all variables which also entered the regressions of Table 1. To account for

\footnotetext{
17 Random effects models are rejected by a Hausman test in most cases, for some specifications a usual Hausman test could not be calculated, because of problems of invertability of the covariance matrix.
} 
technological differences and other effects of particular industries, we also include in addition the log average real wage of the industry in which the respective firm is operating.

Table 3

Columns 2 and 4 of Table 3 present the results of the between-firm (group-means) regressions. The estimates are weighted by the number of periods a firm is observed in the sample. It turns out that wage inequality has a significant impact on standardised wages of both white collar and blue collar workers with point estimates quantitatively much larger than in the case of within-firm effects. For white-collar workers the estimates imply a hump-shaped picture, just like that in the OLS regression of Table 1. This result remains qualitatively unchanged once we confine the analysis to observations where inequality indicators were calculated only for male employees (Table 4, Column 4).

For blue-collar wages a hump-shaped pattern also emerges. Here however, the turning point is much later: at a value of firm wage inequality sigma of 0.28 in Table 3 . This means, that for the most part of the empirical distribution of the inequality measure sigma, a positive dispersion-wage schedule can be observed. This result is again very similar to the OLSregression in Table 1. If the firm inequality measure is based only on males, the results for blue-collar workers turn out to be less robust. The point estimates indicate a rising inequalitywage schedule, but the coefficients are not significant (Column 2 in Table 4).

Table 4

\section{Conclusions}

A firm's pay structure is an important determinant of firm performance. Although there has been a lot of research on optimal incentive schemes in firms, the empirical literature is relatively sparse. This paper is one of the first attempts to evaluate the impact of wage dispersion within firms on firm productivity. Due to the lack of variables on the firms' financial performance, we use standardised wage levels as our performance indicators. 
In the case of white-collar wages the relationship is found to be non-monotonic. For low levels of wage dispersion more inequality seems to be beneficial for earnings. If dispersion grows too high, however, this is detrimental in terms of productivity.

For blue-collar wages the situation is different. For the most part of the observed range of inequality in firms, standardised wages rise with wage dispersion. Our findings are consistent with the hypothesis that too little inequality is harmful for productivity due to a lack of incentives. Alternatively, there could be a fairness constraint leading to less efficient outcomes when inequality becomes too large. Our results are not compatible with theories of tournaments, with simple models of risk aversion and with models of union influence. Our contrasting results for blue- and white-collar workers are neither inconsistent with the prevalence of piece rates in blue-collar jobs, nor with theories of intrinsic motivation and rentseeking within the firm.

These findings are only a first step. Further research should concentrate on the direct relationship between directly on financial performance and intra-firm wage inequality but also on the implications of wage dispersion for the mobility behaviour (turnover and quits) of workers in the firm. 


\section{References}

Adams, Stacy J. (1963). Towards an Understanding of Inequity, Journal of Abnormal and Social Psychology. 75: 422-436.

Agell, Jonas and Per Lundborg (1995). Theories of Pay and Unemployment: Survey Evidence from Swedish Manufacturing Firms, Scandinavian Journal of Economics. 97: 295-307.

Akerlof, George A. and Janet L. Yellen (1990). The Fair Wage-Effort Hypothesis and Unemployment, Quarterly Journal of Economics. 105: 255-283.

Baker, George, Gibbs, Michael and Bengt Holmstrom (1994). The Wage Policy of a Firm, Quarterly Journal of Economics. 109: 921-954.

Baker, George, Gibbs, Michael and Bengt Holmstrom (1994). The internal Economics of the Firm: Evidence from Personnel Data, Quarterly Journal of Economics. 109: 881-919.

Bewley, Truman F.: Why Not Cut Pay? (1998). European Economic Review. 42: 459-490.

Blanchflower, David G., Oswald, Andrew J. and Peter Sanfey (1996). Wages, Profits and Rent-sharing, Quarterly Journal of Economics: 111: 227-252.

Blanchflower, David G. Oswald, Andrew J. and Mario D. Garrett (1990). Insider Power in Wage Determination, Economica. 57: 143-170.

Blinder, Alan S. and D. H. Choi (1990). A Shred of Evidence on Theories of Wage Stickiness, Quarterly Journal of Economics. 105: 1003-1015.

Brown, Charles and Medoff James (1989). The Employer Size Wage Effect, Journal of Political Economy. 97: 1027-1059.

Cowherd, Douglas M. and David I. Levine (1992). Product Quality and Pay Equity between Lower-level Employees and Top Management: An Investigation of Distributive Justice Theory, Administrative Science Quarterly. 37: 302-320.

Davis, Steve J. and John Haltiwanger (1996). Employer Size and the Wage Structure in U.S. Manufacturing, Annales d'Économie et de Statistique, 323-368.

Falkinger, Josef (1999). Social instability and redistribution of income, European Journal of Political Economy (forthcoming).

Fehr, Ernst, Simon Gächter and Georg Kirchsteiger (1996). Reciprocal Fairness and Noncompensating Wage Differentials, Journal of Institutional and Theoretical Economics. 152: 608-640.

Fichtenbaum, R. and H. Shahidi (1988). Truncation Bias and the Measurement of Income Inequality, Journal of Business and Economic Statistics. 
Freeman, Richard B. (1982). Union Wage Practices and Wage Dispersion within Establishments, Industrial and Labor Relations Review. 36: 3-21.

Frey, Bruno S. (1997). Not Just for the Money: An Economic Theory of Personal Motivation, Edward Elgar (Cheltenham).

Frey, Bruno S. and Margit Osterloh (1997). Sanktionen oder Seelenmassage? Motivationale Grundlagen der Unternehmensführung, Die Betriebswirtschaft 57: 307-321.

Gächter, Simon and Armin Falk (1998). Work Motivation and Performance: How Can Incomplete Employment Contracts Be Enforced?, University of Zurich, Working Paper.

Gusenleitner, Markus, Winter-Ebmer, Rudolf and Josef Zweimüller (1998). Earnings inequality in Austria: 1972 - 1991, Allgemeines Statistisches Archiv, 275-290.

Hibbs, Douglas A. Jr. and Hakan Locking (1995). Wage Dispersion and Productive Efficiency: Evidence for Sweden, Trade Union Institute for Economic Research, Stockholm, Working Paper.

Lazear, Edward P. (1989). Pay Equality and Industrial Politics), Journal of Political Economy 97: $561-580$.

Lazear, Edward P. and Sherwin Rosen (1989). Rank-Order Tournaments as Optimum Labor Contracts, Journal of Political Economy. 89: 841-864.

Lazear, Edward P. (1996). Performance Pay and Productivity, Hoover Institution, Working Paper.

Leonard, Jonathan S. (1990). Executive Pay and Firm Performance, Industrial and Labor Relations Review. 43: 13S-29S.

Levine, David I. (1991). Fairness, Markets, and Ability to Pay: Evidence from Compenstion Executives, American Economic Review. 83: 1241-1259.

Levine, David I. (1991). Cohesiveness, Productivity, and Wage Dispersion: Journal of Economic Behavior and Organisation. 15: 237-255.

Milgrom, Paul R. (1988). Employment Contracts, Influence Activities, and Efficient Organisation Design, Journal of Political Economy. 96: 42-60.

Milgrom, Paul and John Roberts (1990). The Efficiency of Equity in Organisational Decision Processes, American Economic Review, Papers and Proceedings. 80: 154-159.

Milgrom, Paul R. and John Roberts (1992). Economics, Organisation, and Management, Prentice Hall. 
Pfeffer, Jeffrey and Alison Davis-Blake (1992). Salary Dispersion, Location in the Salary Distribution, and Turnover among College Administrators, Industrial and Labor Relations Review. 45: 753-763.

Winter-Ebmer, Rudolf (1994). Endogenous Growth, Human Capital, and Industry Wages, Bulletin of Economic Research. 4: 289-314.

Winter-Ebmer, Rudolf and Josef Zweimüller (1996). Immigration and the Earnings of Young Native Workers, Oxford Economic Papers. 48: 473-491.

Winter-Ebmer, Rudolf and Josef Zweimüller (1999). Firm Size Wage Differentials in Switzerland: Evidence from Job Changers, American Economic Review, Papers and Proceedings, forthcoming. 
Table 1: $\quad$ OLS Firm-Level Wage Regressions

\section{Blue-Collar Workers $\quad$ White-Collar Workers}

\begin{tabular}{|c|c|c|}
\hline $\begin{array}{l}\text { Firm wage inequality } \\
\text { (sigma) }\end{array}$ & $\begin{array}{c}2.699 \\
(4.044)\end{array}$ & $\begin{array}{l}5.175 \\
(8.95)\end{array}$ \\
\hline Sigma $^{2}$ & $\begin{array}{l}-4.632 \\
(3.26)\end{array}$ & $\begin{array}{c}-11.279 \\
(9.14)\end{array}$ \\
\hline$\%$ age under 25 & $\begin{array}{l}-0.413 \\
(4.07)\end{array}$ & $\begin{array}{l}-0.870 \\
(10.07)\end{array}$ \\
\hline$\%$ age over 50 & $\begin{array}{l}-0.689 \\
(5.24)\end{array}$ & $\begin{array}{l}-0.598 \\
(4.44)\end{array}$ \\
\hline $\log ($ firm size $)$ & $\begin{array}{l}0.014 \\
(1.00)\end{array}$ & $\begin{array}{l}-0.064 \\
(5.07)\end{array}$ \\
\hline$\%$ blue-collar & $\begin{array}{l}0.634 \\
(13.7)\end{array}$ & $\begin{array}{l}0.235 \\
(6.00)\end{array}$ \\
\hline$\%$ foreigners & $\begin{array}{l}0.308 \\
(2.22)\end{array}$ & $\begin{array}{l}-0.053 \\
(0.37)\end{array}$ \\
\hline$\%$ women & $\begin{array}{l}-0.109 \\
(2.59)\end{array}$ & $\begin{array}{l}-0.205 \\
(4.98)\end{array}$ \\
\hline$\%$ tenure over 3 years & $\begin{array}{l}-0.067 \\
(1.24)\end{array}$ & $\begin{array}{c}-0.040 \\
(0.76)\end{array}$ \\
\hline $\mathrm{N}$ (\# of firms $\mathrm{x}$ years) & 1164 & 1175 \\
\hline $\operatorname{adj} R^{2}$ & 0.252 & 0.250 \\
\hline F-Test 18 & $11.93 * * *$ & $15.83^{* * *}$ \\
\hline
\end{tabular}

18

F-Test for joint significance of sigma and sigma ${ }^{2}$, $t$-values in paranthesis. 
Table 2: Robustness checks for wage regressions

Blue-collar workers White-collar workers

\begin{tabular}{lcc}
\hline Firm wage inequality & 1.705 & 3.939 \\
(sigma) & $(3.50)$ & $(8.95)$ \\
Sigma $^{2}$ & -2.331 & -8.888 \\
& $(2.15)$ & $(9.01)$ \\
\hline F-Test for joint significance & $14.28 * * *$ & $38.72 * * *$ \\
$\mathrm{~N}$ & 1062 & 1072 \\
\hline
\end{tabular}

Notes: Firm inequality indicator "sigma" is calculated using only male workers in the firm, t-values in paranthesis 


\section{Table 3:}

Firm Wage Inequality and Firm Performance: Within and Between Firm Effects

Blue-collar wage

fixed effects estimates
White-collar wage

fixed effects group means estimates regression

\begin{tabular}{|c|c|c|c|c|}
\hline & estimates & regression & estimates & regression \\
\hline $\begin{array}{l}\text { Firm wage inequality } \\
\text { (sigma) }\end{array}$ & $\begin{array}{l}-0.251 \\
(0.48)\end{array}$ & $\begin{array}{l}8.710 \\
(3.11)\end{array}$ & $\begin{array}{l}1.079 \\
(2.12)\end{array}$ & $\begin{array}{l}8.341 \\
(4.51)\end{array}$ \\
\hline Sigma $^{2}$ & $\begin{array}{l}0.732 \\
(0.70)\end{array}$ & $\begin{array}{c}-15.418 \\
(2.48)\end{array}$ & $\begin{array}{c}-1.330 \\
(1.31)\end{array}$ & $\begin{array}{c}-17.659 \\
(4.31)\end{array}$ \\
\hline$\%$ age under 25 & $\begin{array}{l}-0.062 \\
(0.69)\end{array}$ & $\begin{array}{l}-0.563 \\
(1.45)\end{array}$ & $\begin{array}{l}-0.309 \\
(3.41)\end{array}$ & $\begin{array}{l}-0.939 \\
(3.68)\end{array}$ \\
\hline$\%$ age over 50 & $\begin{array}{l}-0.140 \\
(1.18)\end{array}$ & $\begin{array}{r}-0.830 \\
(1.58)\end{array}$ & $\begin{array}{l}0.057 \\
(0.05)\end{array}$ & $\begin{array}{l}-0.449 \\
(1.02)\end{array}$ \\
\hline $\log ($ firm size $)$ & $\begin{array}{l}0.021 \\
(0.95)\end{array}$ & $\begin{array}{l}0.002 \\
(0.04)\end{array}$ & $\begin{array}{l}-0.018 \\
(0.67)\end{array}$ & $\begin{array}{l}-0.045 \\
(1.38)\end{array}$ \\
\hline$\%$ blue-collar & $\begin{array}{l}-0.127 \\
(0.98)\end{array}$ & $\begin{array}{l}1.059 \\
(6.94)\end{array}$ & $\begin{array}{l}0.160 \\
(1.21)\end{array}$ & $\begin{array}{l}0.423 \\
(4.09)\end{array}$ \\
\hline$\%$ foreigners & $\begin{array}{l}0.176 \\
(1.06)\end{array}$ & $\begin{array}{l}0.259 \\
(0.54)\end{array}$ & $\begin{array}{l}0.353 \\
(2.11)\end{array}$ & $\begin{array}{l}-0.054 \\
(0.13)\end{array}$ \\
\hline$\%$ women & $\begin{array}{l}-0.555 \\
(4.84)\end{array}$ & $\begin{array}{l}0.218 \\
(1.65)\end{array}$ & $\begin{array}{l}-0.168 \\
(1.43)\end{array}$ & $\begin{array}{l}0.119 \\
(1.21)\end{array}$ \\
\hline$\%$ tenure $>3$ years & $\begin{array}{l}-0.200 \\
(2.78)\end{array}$ & $\begin{array}{l}0.107 \\
(0.46)\end{array}$ & $\begin{array}{l}-0.124 \\
(2.85)\end{array}$ & $\begin{array}{l}-0.069 \\
(0.36)\end{array}$ \\
\hline Log (industry wage) & - & $\begin{array}{c}0.808 \\
(19.09)\end{array}$ & - & $\begin{array}{c}0.962 \\
(31.15)\end{array}$ \\
\hline $\mathrm{N}$ & 1164 & 123 & 1175 & 126 \\
\hline
\end{tabular}

Note: Group means regressions; weighted least squares 
Table 4:

Robustness checks: within- and between-firm effects

\begin{tabular}{lcccc}
\hline & \multicolumn{2}{c}{ Blue-collar workers } & \multicolumn{2}{c}{ White-collar workers } \\
& $\begin{array}{c}\text { fixed-effect } \\
\text { estimate }\end{array}$ & $\begin{array}{c}\text { group-means } \\
\text { regression }\end{array}$ & $\begin{array}{c}\text { fixed-effect } \\
\text { estimate }\end{array}$ & $\begin{array}{c}\text { group-means } \\
\text { regression }\end{array}$ \\
\hline Firm wage inequality & 0.403 & 5.027 & 0.662 & 9.820 \\
$($ Sigma) & $(1.12)$ & $(1.83)$ & $(1.91)$ & $(5.59)$ \\
Sigma $^{2}$ & -0.934 & -6.702 & -1.486 & -22.413 \\
& $(1.28)$ & $(0.99)$ & $(2.12)$ & $(5.24)$ \\
\hline $\mathrm{N}$ & 1062 & 110 & 1072 & 112 \\
\hline
\end{tabular}

Notes: Sigma calculated using only male workers in the firm; group means regressions; weighted least squares) $t$-values in paranthesis. 